Polymer Journal, Vol. 8, No. 4, pp 385-387 (1976)

SHORT COMMUNICATION

\title{
The Helix-Coil Transition of DNA by Mercuric Ion
}

\author{
Yoshihiro BABA and Akihiro Kagemoto \\ Department of General Education, Osaka Institute of Technology, \\ 5-Chome, Omiya, Asahi-ku, Osaka 535, Japan.
}

(Received November 7, 1975)

\begin{abstract}
KEY WORDS DNA / Mercuric Ion / Heat of Transition / Heat of Mixing / UV Spectrum /
\end{abstract}

As reported in a previous paper, ${ }^{1}$ we have measured the heat of the helix-coil transition of DNA solutions with different concentrations of $\mathrm{Mg}^{2+}$ ions by using a modified DSC, and found that the transition temperature of DNA depends on both the concentrations of $\mathrm{Mg}^{2+}$ ion and of DNA; the heat of the helix-coil transition of DNA is estimated to be about 40 $\mathrm{kJ}$ per base pair mole at a mole ratio of 1 for $\mathrm{Mg}^{2+}$ to $\mathrm{DNA}(\mathrm{P})$, corresponding to $1 \mathrm{~mol}$ of $\mathrm{Mg}^{2+}$ binding to $1 \mathrm{~mol}$ of phosphate of DNA.

In 1961, the influence of mercuric ion on DNA was studied by Yamane, et al., ${ }^{2}$ using a spectrophotometer; they reported that DNA in $\mathrm{HgCl}_{2}$ solution may form a DNA $-\mathrm{Hg}^{2+}$ complex. In this paper, in order to substantiate this possibility and to obtain more information about the behavior of DNA in the $\mathrm{HgCl}_{2}$ solution, the influence of $\mathrm{Hg}^{2+}$ on the helix-coil transition of DNA has been studied by using the modified DSC and the microcalorimeter.

Calf thymus (GC content $43 \%$ ) was purchased from Miles Co. Ltd. The buffer solution used in this study was $1 \mathrm{mM}$ acetate solution ( $\mathrm{pH}$ 5.72). The DNA sample was dissolved in the buffer solution with different $\mathrm{HgCl}_{2}$ concentrations and allowed to stand overnight at $278 \mathrm{~K}$ in order to obtain a homogeneous solution.

For the DSC measurement, the DNA concentration was about $0.2 \%$; this was determined by measurement of the absorption spectrum at $260 \mathrm{~nm}$ taking $E(\mathbf{P})=6300$ at this wavelength.

For the calorimetric measurement, the DNA concentration was about one-tenth that for the DSC measurement.

The DSC (Model M8005, Rigaku Denki Co.

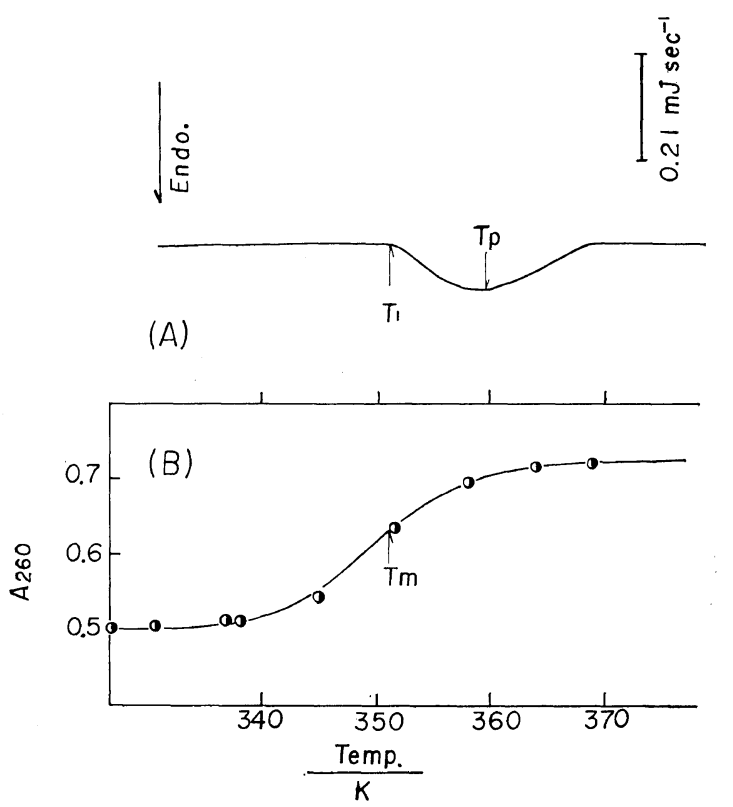

Figure 1. (A) A typical DSC curve of DNA solution: DNA, $0.24 \% ; \mathrm{HgCl}_{2}, 2 \times 10^{-4} \mathrm{~mol}$; buffer solution, $1 \mathrm{~m} M$ acetate ( $\mathrm{pH}$ 5.72). $T_{1}$ and $T_{\mathrm{p}}$ are the initial departure and peak temperatures, respectively. (B) The plot of absorbance at $260 \mathrm{~nm}$ against the temperature. $T_{m}$ is the helix-coil transition temperature.

Ltd.) used in this study was modified so as to be able to measure slight changes in the heat of a small quantity of a sample; the calorimeter used in the measurement of the heat of mixing of the DNA- $\mathrm{HgCl}_{2}$ system was similar to the LKB batch micro calorimeter. The cell for mixing was made of glass instead of gold.

The thermal behavior for DNA dissolved in 
$1 \mathrm{mM}$ acetate buffer solution with $\mathrm{Hg}^{2+}$ was studied by the modified DSC. The heating rate in this study was about $10 \mathrm{~K} / \mathrm{min}$. The DSC curve obtained is shown in Figure 1A; it has an endothermic peak with a temperature width of 15 to $20 \mathrm{~K}$. To confirm the endothermic peak obtained from the DSC curve, the dependence of the absorbance on the temperature was studied by using the spectrophotometer.

The plot of the absorbance at a wavelength of $260 \mathrm{~nm}$ against the temperature is shown in Figure 1B, together with the DSC curve. As seen in Figure 1B, the helix-coil transition temperature $\left(T_{\mathrm{m}}\right)$ of DNA obtained is about 353K. Accordingly, $T_{\mathrm{m}}$ corresponds to the temperature $\left(T_{1}\right)$ where the peak begins to appear rather than the peak temperature $\left(T_{p}\right)$ on the DSC curve. Thus, an endothermic peak appearing on a DSC curve may be considered to

Table I. Transition temperature $\left(T_{1}\right)$ and heat of transition $\left(\Delta H_{\mathrm{m}}\right)$ estimated from DSC method (the second column), wavelength of maximum absorption $\left(\lambda_{\max }\right)$ and transition temperature $\left(T_{\mathrm{m}}\right)$ from spectrophotometer (the third column), and heat of mixing $\left(\Delta H^{\mathrm{M}}\right)$ from micro calorimeter (the last column) for $\mathrm{DNA}-\mathrm{Hg}^{2+}$ ion system, respectively

\begin{tabular}{|c|c|c|c|c|c|}
\hline \multirow{2}{*}{$\begin{array}{c}r=\mathrm{Hg}^{2+} / \\
\operatorname{DNA}(\mathrm{P})\end{array}$} & \multicolumn{2}{|c|}{ DSC } & \multicolumn{2}{|c|}{ Spectra } & \multirow{2}{*}{$\frac{\begin{array}{c}\text { Heat of } \\
\text { mixing }\end{array}}{\begin{array}{c}\Delta H^{\mathrm{M}} \\
\mathrm{kJ} \cdot(\mathrm{bpm})^{-1}\end{array}}$} \\
\hline & $\begin{array}{l}T_{1} \\
\mathrm{~K} \quad \mathrm{k}\end{array}$ & $\begin{array}{c}\Delta H_{\mathrm{m}} \\
\mathrm{JJ} \cdot(\mathrm{bpm})^{-1}\end{array}$ & $\underset{\mathrm{K}}{T_{\mathrm{m}}}$ & $\begin{array}{c}\lambda_{\max }, \\
\mathrm{nm}\end{array}$ & \\
\hline 0 & 353.0 & 31.1 & 353 & 258 & \\
\hline $1.20 \times 10^{-4}$ & 352.3 & 32.7 & - & - & \\
\hline $7.80 \times 10^{-3}$ & 353.7 & 31.4 & - & - & 0 \\
\hline $2.56 \times 10^{-2}$ & 351.6 & 32.3 & 350 & 259 & - \\
\hline $6.86 \times 10^{-2}$ & 352.6 & 22.6 & - & - & 0.10 \\
\hline $9.12 \times 10^{-2}$ & 354.1 & 22.5 & - & - & - \\
\hline 0.11 & & & 351 & 260 & - \\
\hline 0.15 & & & 350 & 262 & 1.07 \\
\hline 0.18 & & & 350 & 263 & 1.75 \\
\hline 0.45 & & & 350 & 265 & 5.57 \\
\hline 0.60 & & & - & - & 8.53 \\
\hline 0.71 & & & 350 & 268 & 9.54 \\
\hline 1.05 & & & $\begin{array}{c}\text { not } \\
\text { present }\end{array}$ & $t^{271}$ & 21.04 \\
\hline 1.09 & & & & & 23.94 \\
\hline 1.65 & & & $"$ & 275 & - \\
\hline 1.92 & & & " & 273 & 28.74 \\
\hline 4.08 & & & & & 28.38 \\
\hline 5.65 & & & & & 26.68 \\
\hline
\end{tabular}

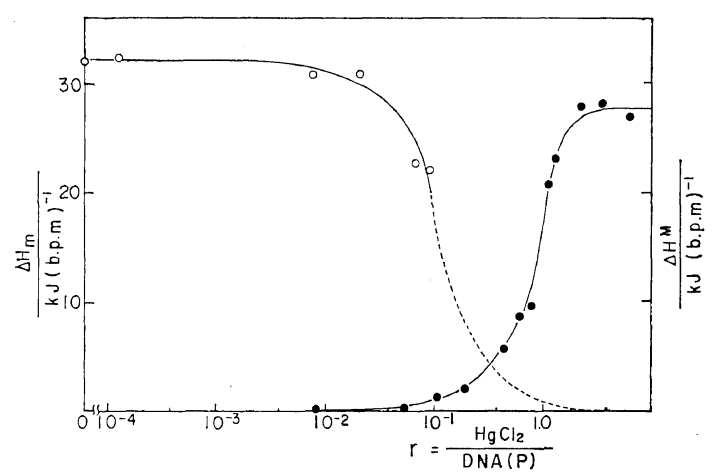

Figure 2. The plots of $\Delta H_{\mathrm{m}}(\bigcirc)$ and $\Delta H^{\mathrm{M}}$ of $\mathrm{DNA}-\mathrm{Hg}^{2+}$ system against $r$ (=mole added $\mathrm{HgCl}_{2} /$ mole phosphate of DNA). The dotted line of $\Delta H_{\mathrm{m}}$ gives the expected phase diagram; it can not be measured because of the amalgam between the aluminum DSC cell and mercuric ion in excess $\mathrm{HgCl}_{2}$.

correspond to the helix - coil transition of DNA.

Assuming that an endothermic peak in the DSC curve is due to the helix-coil transition of DNA, the heat of the helix-coil transition of DNA can be estimated from the peak area of DSC curve. The results obtained are listed in the second column in Table I. Using Table I, the plot of the heat of helix-coil transition per base pair mole $\left(\Delta H_{\mathrm{m}}\right)$ against $r$ (=mole of $\mathrm{HgCl}_{2} /$ mole of $\mathrm{DNA}(\mathrm{P})$ ) is shown in Figure 2. When $r$ is more than 0.1 , a DSC measurement is impossible because an amalgam is formed between the aluminum cell of DSC and the mercury. Then, the dotted line of $\Delta H_{\mathrm{m}}$ is drawn from the results of the spectrophotometric measurement.

Where $r$ is less than $10^{-2}, \Delta H_{\mathrm{m}}$ has a definite value of about $31 \mathrm{~kJ}$ which is nearly independent of the concentration of $\mathrm{Hg}^{2+}$. When $r$ is more than $10^{-2}$, a drastic decrease of $\Delta H_{\mathrm{m}}$ occurs and the wavelength of maximum absorption $\left(\lambda_{\max }\right)$ increases, as shown in Table I. In order to explain these facts, we may assume that the following equilibrium exists among DNA(helix)$\mathrm{Hg}^{2+}$ complex, DNA(coil) $-\mathrm{Hg}^{2+}$ complex, and $\mathrm{Hg}^{2+}$ :

$$
\text { DNA(helix) }-\mathrm{Hg}^{2+}+\mathrm{Hg}^{2+} \rightleftharpoons \mathrm{DNA}(\text { coil })-\mathrm{Hg}^{2+}
$$

When the concentration of $\mathrm{Hg}^{2+}$ is so low that $r$ is less than $10^{-2}$, the mainly existing molecules 
may be DNA(helix) $-\mathrm{Hg}^{2+}$ and the $\Delta H_{\mathrm{m}}$ accompanying the helix-coil change will be large. On the other hand, when the concentration of $\mathrm{Hg}^{2+}$ becomes so large that $r$ is more than $10^{-2}$, the equilibrium moves to the right and the number of DNA(helix) $-\mathrm{Hg}^{2+}$ becomes smaller as $r$ increases, suggesting that $\Delta H_{\mathrm{m}}$ decreases as $r$ increases.

In order to obtain further information, the heats of mixing of DNA and $\mathrm{HgCl}_{2}$ solutions have been measured by using the microcalorimeter at $298 \mathrm{~K}$. The results obtained are listed in the last column in Table I. Using Table I, the plot of the heat of mixing per base pair mole $\left(\Delta H^{\mathrm{M}}\right)$ against $r$ is shown in Figure 2, together with $\Delta H_{\mathrm{m}}$. This plot may be interpreted as follows. The heat of mixing of the DNA- $\mathrm{HgCl}_{2}$ system may be assumed to consist of the following two steps:

DNA(helix) +a small amount of

$$
\mathrm{Hg}^{2+} \stackrel{\Delta H_{1}}{\rightleftharpoons} \mathrm{DNA}(\text { helix })-\mathrm{Hg}^{2+}
$$

DNA(helix) $-\mathrm{Hg}^{2+}+\mathrm{a}$ large amount of

$$
\mathrm{Hg}^{2+} \stackrel{\Delta H_{2}}{\rightleftharpoons} \mathrm{DNA}(\text { coil })-\mathrm{Hg}^{2+}
$$

Then the heat of mixing $\Delta H^{\mathrm{M}}$ as $r \rightarrow \infty$ will be equal to the sum of $\Delta H_{1}$ and $\Delta H_{2}$ of the above two steps, and $\Delta H_{2}$ may be expected to increase with the concentration of $\mathrm{Hg}^{2+}$, that is, with $r$, and to attain its maximum at a larger value of $r$, in close agreement with the curve in Figure 2. On the other hand, $\Delta H_{\mathrm{m}}$, when $r$ is very small, corresponds to the process, DNA(helix)$\mathrm{Hg}^{2+} \rightarrow \mathrm{DNA}$ (coil) $-\mathrm{Hg}^{2+}$, which is equal to the second step of the mixing. Therefore, $\Delta H_{\mathrm{m}}$ as $r \rightarrow 0$ may be considered to be equal to the maximum value of $\Delta H_{2}$. Using the relation $\Delta H_{2}=\Delta H^{\mathbb{M}}-\Delta H_{1}$, the following value will be obtained:

$$
\Delta H_{\mathrm{m}}(r \rightarrow 0)=\Delta H^{\mathrm{M}}(r \rightarrow \infty)-\Delta H_{1}
$$

As $\Delta H_{\mathrm{m}}(r \rightarrow 0)=31 \mathrm{~kJ}$ and $\Delta H^{\mathrm{M}}=28 \mathrm{~kJ}$, then $\Delta H_{1}$ will be estimated to be $-3 \mathrm{~kJ}$.

\section{REFERENCES}

1. Y. Baba and A. Kagemoto, Biopolymers, 13, 339 (1974).

2. T. Yamane and N. Davidson, J. Amer. Chem. Soc., 83, 2599 (1961). 